\title{
Inflammation-sleep interface in brain disease: TNF, insulin, orexin
}

Ian A Clark ${ }^{1 *}$ and Bryce Vissel ${ }^{2}$

\begin{abstract}
The depth, pattern, timing and duration of unconsciousness, including sleep, vary greatly in inflammatory disease, and are regarded as reliable indicators of disease severity. Similarly, these indicators are applicable to the encephalopathies of sepsis, malaria, and trypanosomiasis, and to viral diseases such as influenza and AIDS. They are also applicable to sterile neuroinflammatory states, including Alzheimer's disease, Parkinson's disease, traumatic brain injury, stroke and type-2 diabetes, as well as in iatrogenic brain states following brain irradiation and chemotherapy. Here we make the case that the cycles of unconsciousness that constitute normal sleep, as well as its aberrations, which range from sickness behavior through daytime sleepiness to the coma of inflammatory disease states, have common origins that involve increased inflammatory cytokines and consequent insulin resistance and loss of appetite due to reduction in orexigenic activity. Orexin reduction has broad implications, which are as yet little appreciated in the chronic inflammatory conditions listed, whether they be infectious or sterile in origin. Not only is reduction in orexin levels characterized by loss of appetite, it is associated with inappropriate and excessive sleep and, when dramatic and chronic, leads to coma. Moreover, such reduction is associated with impaired cognition and a reduction in motor control. We propose that advanced understanding and appreciation of the importance of orexin as a key regulator of pathways involved in the maintenance of normal appetite, sleep patterns, cognition, and motor control may afford novel treatment opportunities.
\end{abstract}

Keywords: Alzheimer's disease, coma, encephalopathy, IL-1, orexin, Parkinson's disease, sleep, stroke, TNF, traumatic brain injury

\section{Introduction: TNF and IL-1 in disease pathogenesis}

A number of proinflammatory (and indeed antiinflammatory) cytokines exist, but for conciseness, comments will largely be restricted to tumor necrosis factor (TNF) and interleukin-1 (IL-1). In practice, this will mean IL- $1 \beta$, since its twin, IL- $1 \alpha$, mostly avoids assay by remaining cell-bound, and is thus absent from serum. In brief, TNF activates NLRP3, a NOD-like receptor, which in turn activates caspase- 1 , which, as the IL- $1 \beta$ cleavage enzyme, converts the TNF-induced precursor, pro-IL-1 $\beta$, to active IL-1 $\beta$ [1]. Studies in a rheumatoid arthritis context make the case for TNF being the master cytokine that initiates the inflammatory cascade [2]. In addition, being the specific target of a number of

\footnotetext{
* Correspondence: ian.clark@anu.edu.au

'Biomedical Sciences and Biochemistry, Research School of Biology, Australian National University, Acton, Canberra, Australian Capital Territory 0200, Australia

Full list of author information is available at the end of the article
}

biological drugs in wide use gives TNF high profile in the disease literature. TNF and IL-1 share many functions [3], including the capacity to induce each other and interleukin-6 (IL-6) [4]. This cytokine has a number of important activities, and is often a convenient marker for inflammatory reactions because it appears in the circulation later, when illness is more evident, and it remains at higher levels for longer than either IL-1 or TNF. Both TNF [5] and IL-1 [6] are phylogenetically ancient, as are orexin (hypocretin) [7] and insulin [8], two mediators discussed here because of their functional alliance to TNF and IL-1, arguably present for many millions of years.

Both TNF and IL-1 have proved to be both ubiquitous and pleiotropic, and if one is present, the other typically will be also. While often grouped on their capacity to mediate innate immunity, they have physiological and disease roles that, at least in the literature, overshadow their immune functions. Hence, while often termed 
proinflammatory cytokines, in increasing concentrations they modulate normal physiology (including physiological sleep), the innate arm of the immune system, and inflammatory disease processes and progression. This occurs in conditions caused by infectious agents in general [9], and, as well as those discussed in this text, Crohn's diseases [10], psoriasis [11], spondyloarthritis [12], rheumatoid arthritis [13], amyotrophic lateral sclerosis [14], Behçet's disease [15], graft-versus-host disease [16], acute heart failure [17], preeclampsia [18], and autoimmunity in general, as well as aspects of the illness that accompanies malignancies [19].

\section{Inflammatory cytokines and sleep}

Interferon was one of the first (1983) cytokines to be implicated in sleep [20] but has been less investigated than others, probably because its species specificity limits generalizations. The following year IL-1, previously known as endogenous pyrogen (the link being unexpectedly made because both were identical to serum amyloid Ainducer and lymphocyte-activating factor (LAF) [21]) was first associated with sleep [22]. TNF, first described in 1975 for its in vivo capacity to kill tumor cells [23], was, six years later, shown to kill malaria parasites in vivo, and proposed, along with IL-1 (then known as LAF), to cause the disease complexities of malaria and sepsis [24,25]. While sleep aberrations are part of these conditions, they were not singled out as a particular outcome of the presence of these cytokines. Soon after becoming available in recombinant form, these cytokines were confirmed to be linked to physiological sleep in 1987 [26], and an awareness developed of the metabolic and disease relevance of this association [27]. As reviewed in 1995 [28], this group and others had, by then, done considerable work on these effects being amplified by the increased cytokines generated by microbial infections, and also the implications of their functional redundancy. Moreover, just before the normal time of sleep onset for rats, TNF levels in brain tissue were shown to be 10-fold higher than their daily minimum [29]. Diurnal variations of the soluble TNF receptors (two forms exist, induced by increases in TNF) in plasma from healthy human volunteers are consistent with this model [30]. Key steps in establishing the importance of TNF in sleep were its suppression by an anti-TNF antibody [31] and both spontaneous and influenza-induced sleep being variously altered in double TNF receptor-deficient mice [32]. In brief, when uninfected, these mice had less nonrapid eye movement sleep (NREMS) than wild-type mice at night-time and more rapid eye movement sleep (REMS) than control mice during the day, whereas challenge with mouse-adapted influenza X-31 enhanced NREMS and decreased REMS in both strains to roughly the same extent. In addition, the strain lacking TNF receptors had higher levels of orexin mRNA. As recently summarized [33], wakefulness enhances TNF protein levels and expression in brain, and the highest normal brain levels, at least in the rat, occur at the time of usual sleep onset. Sleep deprivation elevates levels even further, the effects of which we experience in jetlag.

The nocturnal surge of melatonin that arises in the pineal gland, and determines the synchronization of pineal function with the diurnal cycle, has been studied extensively in normal physiology. Melatonin is, however, relatively absent from the literature on sleep variation in disease, with the exception of a recent valuable contribution [34]. In brief, therefore, we note that melatonin is well-recognized as an inhibitor of TNF [35-37], and that TNF, in turn, transiently inhibits its production [38]. Inferences regarding the previous paragraph can be drawn from these observations.

\section{The roles of orexin (hypocretin), including sleep/wake cycles}

Orexin, a pleiotropic neuropeptide recently reviewed in detail [39], is a member of the incretin gene family of peptides $[40,41]$, to which glucagon-like peptide-1 (GLP$1)$, discussed later, belongs. In brief, orexin has two isoforms, orexin A (hypocretin-1) and orexin-B (hypocretin-2), a single precursor protein, and two ubiquitously distributed receptors (OXR1 and OXR2), details of which need not concern a brief overview such as this. As recently reviewed [42], neurons that synthesize orexin are located in the lateral hypothalamus, said to be the key executive function site in the central nervous system. For decades, it has been well documented that this site governs core survival behaviors, such as sleep/ wake cycles, energy metabolism, fight, flight, and food consumption. Typically orexin reaches critical sites in the brain through elaborate innervation throughout the brain, particularly in regions related to wakefulness [43]. Evidence for cerebrospinal fluid (CSF) levels of orexin reflecting its degree of neurotransmission, or even functional meaning, is argued to be still lacking [44]. Indeed, it seems safest to speak of this neuropeptide in terms of the degree of activity in the hypothalamic orexin neuronal network [45]. When levels of this activity are high, it orchestrates the appropriate levels of alertness required for planning and executing goal-oriented behaviors [45]. Low levels of orexin initiate sleep, and very low levels coma. Although still off the beaten path of many medical researchers, this neuropeptide may, in addition to its many other roles, be as close as we have yet come to understanding what modulates sleep depth and the sleep/wake cycle [46]. The involvement of orexin in the sleep pathology of neuroinflammatory diseases is discussed later. 


\section{The concept of sleep rinsing the brain of molecules that accumulate while awake}

In the absence of a lymphatic circulation to remove excess interstitial protein, the brain relies on its interstitial spaces, and thence the CSF, to serve this purpose. A recent report of a dramatic and quite unexpected diurnally cyclic event may well have rewritten assumptions of extracellular fluid flows in the mouse brain [47,48], and thus paved the way for novel explanations of sleep and related phenomena in mammals in general. Briefly, influx into the brain interstitial space of a tracer introduced into the CSF was reduced by $95 \%$ in awake as compared with sleeping mice, arguing that the space to which CSF has access is considerably enlarged during sleep. In other words, the flow of CSF through the interstitial space is reduced during waking to only $5 \%$ of the flow found in sleep. Since an author of this work had earlier shown that interstitial fluid levels of amyloid- $\beta$ $(A \beta)$ in the brains of amyloid precursor protein (APP) transgenic mice correlated with time spent awake, and were significantly increased by chronic sleep restriction [49], radiolabeled soluble $A \beta$ clearance was monitored, and levels were found to fall at twice the rate in sleeping than waking mice. It seems reasonable to predict that other molecules used as markers of Alzheimer's disease (AD), such as pTau, $\alpha$-synuclein and TNF, will prove to clear at the same rate as $A \beta$ during sleep, with practical implications for timing CSF collection when studying patients.

\section{Implication for interpreting recently published data}

Although these observations in mice are yet to be applied to studies of the human brain, or duplicated independently, their capacity to allow alternative interpretations of data is already impressive. For example, infusing the dual orexin receptor antagonist, almorexant, used to treat insomnia, into the cerebral ventricles suppresses the level of $A \beta$ in brain interstitial fluid, and abolishes the natural diurnal variation of $A \beta$ [49]. Moreover, systemic treatment with almorexant once daily for 8 weeks decreased A $\beta$ plaque formation in the brain of APP transgenic mice $[49,50]$. However, almorexant would have considerably increased sleep time, so the period of brain flushing would increase considerably. One can therefore predict that $A \beta$, or any other free molecule in the brain interstitial fluid, would, purely by fluid mechanics, have little opportunity to accumulate post-almorexant. Nor would it show a diurnal pattern.

\section{Implications for normal diurnal changes in brain inflammatory cytokines, and thus $A \beta$}

The passive removal of either TNF or $A \beta$ from the brain interstitial fluid is simply a case of going with the flow, since any protein in the cerebral interstitial space can be expected to be flushed away with the same kinetics as shown for $A \beta$ [48]. Presumably, this regular diurnal removal of TNF would allow the activity of orexigenic neurons in the lateral hypothalamus to rise each morning, gearing up the individual to face the challenges of the day [51]. The more profound question is why, as each awake period progresses, the rise in TNF [33] and $A \beta$ [49] in CSF should occur. Increases in inflammatory cytokines have recently been argued to arise from physiological neuronal activity orchestrating actions of immune cells, vascular cells and neurons [52]. The physiological rise of soluble $A \beta$ in awake subjects can be expected to follow, and be a consequence of, the increase in levels of inflammatory cytokines in the CSF of the human volunteers referred to previously [49], since APP expression [53-55] and its cleavage to A $\beta$ [56-59] require increases in these mediators. These data also explain raised levels of $A \beta$ and $A \beta P P$ proteins in infectious diseases [60-62], since pathogens stimulate TNF generation [9].

\section{Implications for the poor cognition of disturbed and limited sleep}

Common experience shows us that chronically broken or lost sleep has a great cognitive cost, and the link is well documented [63]. Hospital admittance for major surgery illustrates the phenomenon, and procedures such as coronary artery bypass surgery provide an example. They tend to be followed by cognitive decline, and excessive cerebral levels of inflammatory cytokines have been implicated [64], with TNF particularly in the spotlight [65]. Current ideas on how such cytokines increase so dramatically in these patients include volatile anaesthetics [66] and mitochondrial DNA, which, like bacterial DNA is hypomethylated, released from cells disrupted by surgical trauma [67]. An additional contributor to this cytokine increase is likely to be short and fragmented sleep, a well-recognized hazard for hospital patients, especially those undergoing intensive care $[68,69]$. The novel data on diurnal changes in brain interstitial space discussed previously [48] predicts that absence, during intensive care, of the normal nocturnal cerebral rinse provided by a good night's sleep will cause levels of brain TNF, already excessive, to accumulate further, worsening surgery-induced cognitive defects. As recently reviewed [70], the negative effects of sleep deprivation, and the associated effect of increased levels of TNF on learning and memory, synaptic plasticity and expression of cognition-related signaling molecules are active topics of research. A recent study of a wide array of inflammatory markers in healthy young adult volunteers who underwent 40 hours of total sleep deprivation demonstrates the principle [71]. 


\section{Sickness behavior, daytime sleepiness, and insulin resistance}

Excessive generation of TNF and IL-1 in infectious and autoimmune diseases is associated with fever, fatigue, inanition, skeletal muscle catabolism, and a tendency to sleep during normal periods of wakefulness, a syndrome referred to as sickness behavior [72,73]. As has been noted [74], this syndrome appears to be the expression of a central motivational state that reorganizes the organism's priorities to cope with the harmful effects of pathogens. This includes changes in the diurnal pattern, the mechanism for which has been shown to be suppressed expression of the PAR bZip clock-controlled genes $D b p$, Tef, and Hlf and of the period genes Per1, Per2, and Per3 by increased levels of TNF and IL-1, the two moststudied inflammatory cytokines [75]. These authors also reported that increased TNF interferes with the expression of $D b p$ in the suprachiasmatic nucleus and causes prolonged rest periods in the dark, the time when mice normally show spontaneous locomotor activity. Not surprisingly, therefore, elements of sickness behavior characterize all chronic inflammatory diseases, whether or not a pathogen has initiated the event. Should the reorganization of the animal's resources overcome the pathogen or injury, and homeostasis be re-established, all is well. Should, however, the chronic inflammatory response be relentless and the reorganized metabolism and altered diurnal pattern continue unabated, it becomes a liability, potentially leading to a fatal outcome characterized by energy shutdown and anorexia [76]. More acute outcomes have additional distinctive clinical characteristics that have been argued to operate through the same principles [77].

As might therefore be expected, daytime sleepiness is a common manifestation of a disrupted diurnal cycle, and a characteristic of the continuing chronic inflammatory states largely driven by these two cytokines. An example is $\mathrm{AD}$, in which clock gene function, and hence the diurnal cycle, was shown to be distorted [78] some years before it was appreciated that TNF and IL-1 are not only central players in the pathogenesis of this condition but also regulators of clock genes themselves (see previous paragraph). It had already been reported that the duration of daytime sleep in AD correlated with the degree of functional impairment $[79,80]$. Other examples of daytime sleepiness in chronic inflammatory states are Parkinson's disease (PD) $[81,82]$, traumatic brain injury (TBI) $[83,84]$, stroke $[85,86]$, heart failure $[87,88]$, and type-2 diabetes (T2DM) [89].

Clock genes, present in all tissues, are closely orchestrated to maintain normal physiology and diurnal patterns [90]. They undergo insulin-dependent regulation [91]. Circadian clock oscillation is altered in the hearts and livers of mice in which diabetes has been generated with streptozotocin [92], and can be corrected by injecting insulin to overcome insulin resistance. This is consistent with GLP-1 mimetics being therapeutically useful against T2DM through their ability to correct insulin resistance [93], which is evidently present in sickness behavior $[94,95]$. One such agent in regular clinical use, exenatide, has been reported to shorten daytime sleepiness in patients with T2DM [96]. Conceivably this class of agents, being related to orexin (that is, hypocretin), through the incretin family, as mentioned, could also prove, through an ability to correct altered diurnal patterns, to improve daytime sleepiness in the range of conditions discussed in the previous paragraph. As we have recently reviewed [97], GLP-1 mimetics routinely prescribed for T2DM have been reported to improve experimental models of AD (reversed memory impairment and synaptic loss) [98], PD (preserved dopaminergic neurons) [99], TBI (reversed behavioral impairment and memory deficits) $[100,101]$, and stroke (reduced brain damage and improved functional outcome) $[99,102]$.

\section{Orexin in the sleep pathology of inflammatory brain diseases}

Orexin neuron activity is suppressed by bacterial lipopolysaccharide (LPS), a cytokine inducer commonly used to model inflammatory disease, including abnormal sleepiness and anorexia [103-105]. It is also suppressed by TNF (for which LPS is the prototype inducer [23]) predominantly through this cytokine degrading the mRNA of orexin precursor in a time- and dose-dependent manner [106]. One might therefore predict that orexin activity is reduced in states in which consciousness is depressed and TNF is increased, such as TBI, septic encephalopathy, and the post-chemotherapy brain. All three of these conditions have been tested, and shown promise. For example in 44 consecutive TBI patients CSF orexin levels were abnormally low in $95 \%$ of moderately to severely affected individuals 1 to 4 days after trauma [107], and 6 months later levels were still significantly low in patients, with post-traumatic excessive daytime sleepiness [108]. Unfortunately, low orexin is yet to reach the review literature on high levels of TNF in TBI [109]. Mouse TBI data provide compatible orexin results [110], and in conjunction with an anti-TNF report in the same model [111], are ripe for TNF-orexin linkage. A series of reports [112] of TBI cases in which anti-TNF was administered, may then eventually lead to controlled human studies combining these same components.

In a similar vein, a mouse sepsis model has been used to demonstrate, histologically, a six-fold decrease in orexigenic activity in the hypothalamus 48 hours after cecal ligation and puncture [113]. Injecting $3 \mathrm{nmol}$ orexin intracerebroventricular (i.c.v.), an amount and route previously shown to overturn narcolepsy in orexin-deficient 
mice, reversed all changes within an hour. Although this text did not focus on encephalopathy, it relates a transformation, caused by i.c.v. orexin, from lethargy and loss of response to several stimuli to agitation and hyperresponsiveness to the same stimuli. Likewise, poor sleep quality in patients after chemotherapy has been closely linked to their inflammatory markers [114]. In the postchemotherapy brain, the pathogenesis of which involves excess TNF generation [115] and lowered orexigenic activity [116], i.c.v. orexin reversed fatigue (that is, restored voluntary ambulatory activity) in a mouse model [116].

In addition to that seen in sepsis, the encephalopathies of malaria (often referred to as cerebral malaria), trypanosomiasis, AIDS and influenza warrant examining to see if whether orexigenic neuronal activity is depleted, and i.c.v. orexin restores function, since deep prolonged pathological sleep (that is, reversible coma without rationale) and high TNF are already in place [117-122]. The orexin link has already been made with trypanosomiasis [123]. Regarding malaria, recent evidence that LPS suppresses orexigenic activity [105] is consistent with earlier arguments that LPS and malaria generate diseases that are fundamentally the same [124]. Subsequent reports of parallels between septic and malarial encephalopathies noted in immunohistological studies on patient material $[125,126]$ strengthen the case further. The concept is also conceivable for post-radiotherapy brain, in which orexin levels have not been published, but fatigue is notable [127]. Side effects can be ameliorated when either an anti-TNF monoclonal antibody [128] or a GLP-1 mimetic [129], two agents expected to increase orexin output $[106,130]$, is administered soon after irradiation in mouse models. It is also illuminating that the molecular response of the mouse brain within a few hours after lowdose irradiation down-regulates neural pathways associated with cognitive dysfunctions that are also reduced in AD [131]. A GLP-1 mimetic also ameliorates a mouse model of TBI [100,101], one of the high TNF conditions noted to exhibit reduced brain orexin [108,110].

The literature on orexin and both $\mathrm{AD}$ and $\mathrm{PD}$, two conditions characterized by chronic inflammation and circadian alterations that include daytime sleepiness, has a complex history. Potentially, one side of this controversy places these diseases outside the logic arrived at for sepsis, TBI and chemotherapy brain, as discussed. This impression arises from the number of reports that orexin levels in CSF samples are not significantly different in clinical cases and controls in AD [132,133] or in PD $[134,135]$. The alternative arguments, in favor of directly examining the orexigenic activity in the hypothalamus, and of viewing CSF levels as being a diagnostic tool to confirm severe cases rather than useful for understanding pathogenesis of $\mathrm{AD}[136,137]$ and $\mathrm{PD}$ $[44,138,139]$, are consistent with the reasoning and methods employed in the sepsis encephalopathy and chemotherapy literature cited previously. Since i.c.v. orexin is reported to restore function in these conditions $[113,116]$, this second line of reasoning seems the most plausible. Given that high cerebral TNF is a common denominator in these conditions, it is an obvious next experimental step to see $\mathrm{w}$ this increase explains why hypothalamic orexigenic activity is reduced [106] in all the conditions in the previous few paragraphs. Certainly, clarified arguments on a possible key role of orexin in $\mathrm{AD}$ and $\mathrm{PD}$ would, for the reasons outlined, give additional weight to the relevance of anti-TNF agents and GLP-1 mimetics, in which there is already close interest, as rational treatments for these two conditions. It would also add further urgency to developing a specific orexin agonist.

\section{Orexin in cognition, appetite, and water intake}

To understand the role of orexin deficiency in $\mathrm{AD}$ and PD it is also crucial to appreciate that this neuropeptide, which is depressed by TNF, performs a number of key roles in memory acquisition and consolidation [140,141], as well as in long-term potentiation [142-144]. These data are entirely consistent with anti-TNF and GLP-1 mimetics improving cognition, as recently reviewed [97]. Regarding the relative importance of inflammatory pathways (to which orexin belongs, since TNF suppresses it) and $A \beta$ in $A D$, we note that orexin can improve memory, even in mice overproducing $A \beta$ [145]. The poor appetite that is a component of sickness behavior and occurs in chronic inflammatory diseases, such as $\mathrm{AD}$ and PD [146,147], is also consistent [148,149] with orexin inhibition by TNF [106]. Likewise, i.c.v. orexin increases water intake [150], so a reduced physiological thirst response in $\mathrm{AD}[151]$ is not unexpected.

\section{Orexin in motor control}

Several converging lines of evidence are consistent with orexin dependence of central motor control, including the stage being set by direct innervation from the orexigenic hypothalamic neurons to essential subcortical motor structures [152]. In addition, orexigenic neurons are increasingly active during movement [153,154], and injecting orexin into the midbrain triggers locomotion [155]. More recent work [156] has demonstrated that orexin (orexin A, acting via both receptors) enhances the sensitivity of neurons in the lateral vestibular nucleus. Thus, orexigenic activity, increased on demand, is reasoned [156] to regulate the muscle tone required for normal subtleties of vestibular-mediated posture, motor balance, and negative geotaxis. Clearly, these observations have implications for understanding aspects of neurodegenerative diseases in which chronic inflammation down-regulates orexin, as discussed. 


\section{Therapeutic prospects and roles for orexin agonists}

GLP-1 and exenatide, one of its two mimetics in clinical use, have been reported to excite orexin neurons in ex vivo hypothalamic slices [130]. If this translates to in vivo, these agents could be regarded as functionally similar to an orexin agonist. This rationalizes the capacity of GLP-1 mimetics to shorten daytime sleepiness in T2DM, as discussed earlier [96]. Moreover, insulin resistance occurs in orexin knockout mice [157], and hypothalamic orexin prevents insulin resistance in a stress model in mice [158]. Thus, excitation of orexin by exenatide [130] is an additional rationale for GLP-1 mimetics generating positive in vivo outcomes, beyond improving insulin resistance, in experimental models of $\mathrm{AD}$ [98] and PD [99], as well as T2DM. Since TNF inhibits orexin [106], orexin increase through exenatide [130] could be regarded as another anti-TNF effect of the GLP-1 mimetics, and is consistent with the literature on specific anti-TNF agents reducing pathological human sleep [159-162], as it does physiological sleep [31,163]. It also takes our understanding of exenatide shortening daytime sleepiness in T2DM patients [96] to another level.

Another therapeutic possibility for orexin excitation has arisen within the literature on administering the branched-chain amino acids (BCAAs), leucine, isoleucine, and valine. In brief, therapeutic interest in this trio began in the early 1970s when they were reported to reduce the muscle protein catabolism of chronic inflammation [164]. Therefore, BCAAs began to be investigated for possible utility to treat burns, sepsis, and trauma. Their popularity as an uncontrolled over-the-counter diet supplement at least minimizes toxicity concerns, as does a two-year trial in about 650 patients with liver cirrhosis [165]. As recently discussed [166], the scientific challenge has been to integrate various leads and identify a precise focus for BCAA research beyond making itself generally useful by generating more protein. A recent report of oral BCAAs activating orexigenic neurons and also ameliorating sleep fragmentation observed in TBI mice [167] may have provided such a focus. An improvement in power spectral density, which quantifies the strength of electroencephalography (EEG) signals, was also induced by this BCAA therapy. Previous data from this group on BCAAs improving an index of synaptic deficiency in TBI mice [168] is consistent with orexin being required for effective long-term potentiation, as discussed above [142-144].

Developing orexin antagonists to treat insomnia is an active research field [169]. Clearly, a pressing need exists for a specific orexin agonist, or mimetic, small enough to allow its subcutaneous injection because it passes the blood-brain barrier, allowing subcutaneous injection, as do the GLP-1 mimetics. Such a molecule has potential for treating the inflammatory brain states discussed previously, including TBI, $\mathrm{AD}, \mathrm{PD}$, and the encephalopathies of sepsis, AIDS, influenza and malaria, as well as narcolepsy and alcohol toxicity (see [170]). The principle has been demonstrated in very different systems that allow orexin to enter the CSF: intranasal orexin, alleviating cognitive deficits produced by loss of sleep in nonhuman primates [171] and human narcolepsy [172]; i.c.v. administration in an experimental model to treat the severe fatigue that can persist for months or years after chemotherapy [116], and, by the same route, administration to produce arousal effects on acute alcohol intoxication-induced coma in rats [170]. This is not

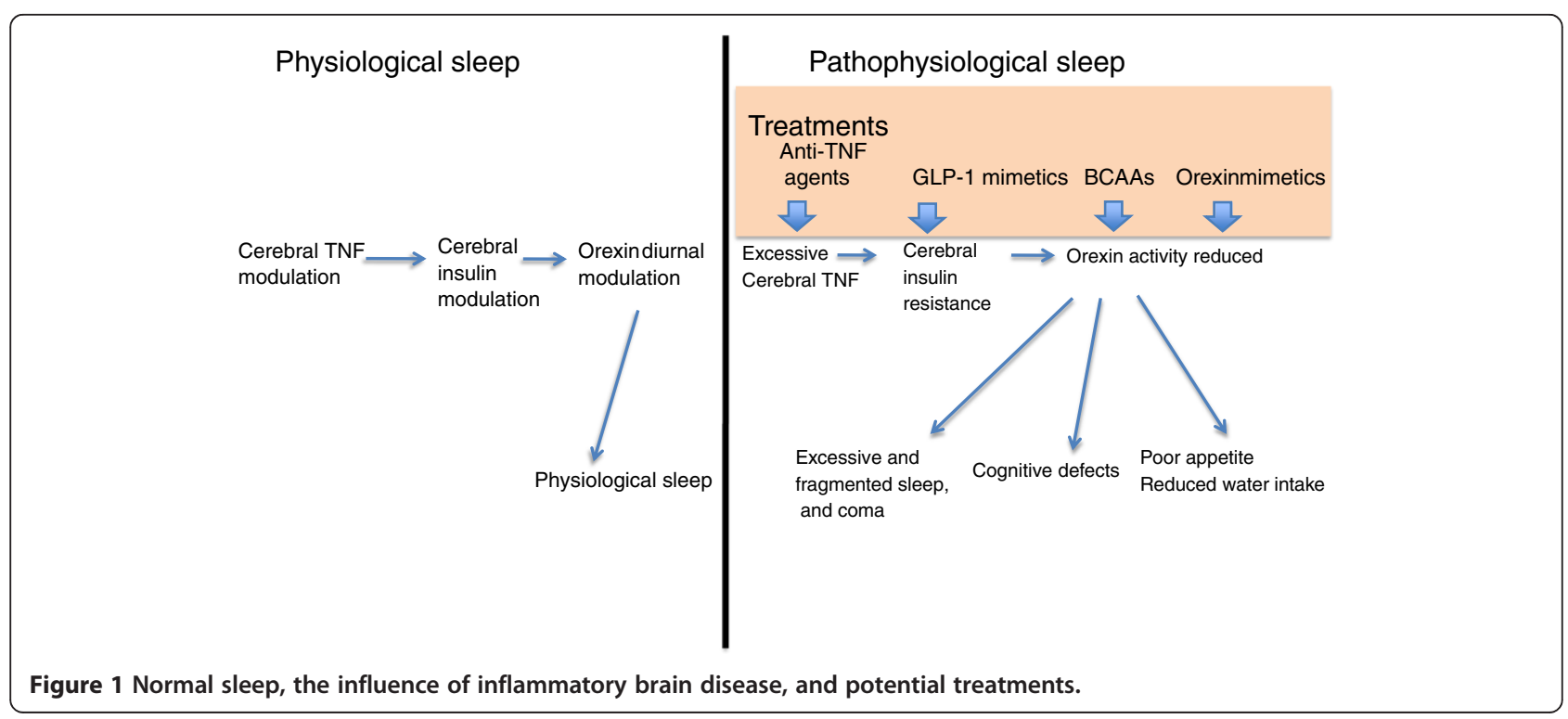


unexpected, since orexin is associated with the regulation of stress, depression, and reward in alcohol dependence [173]. Hence, an orexin mimetic could be a useful addition to anti-TNF agents and GLP-1 mimetics for treating the excessive sleep and coma in inflammatory brain states, as well as their cognitive dimension. A recent orexin-replacing 'designer drug' provides a promising approach [174].

\section{Conclusions}

This review argues the case that, as with other manifestations of inflammatory disease, pathological unconsciousness arises from distortions of the same cytokine and neuropeptide pathways that govern normal sleep. Specifically, the sleep aberrations seen in inflammatory illnesses, ranging from sickness behavior through daytime sleepiness to coma, have a common biological background involving increased inflammatory cytokines and consequent insulin resistance and orexin reduction. The logic of this literature reasons the relevance of antiTNF agents and GLP-1 mimetics in treating these sleep aberrations, as well as the desirability of developing orexin mimetics for the purpose (Figure 1).

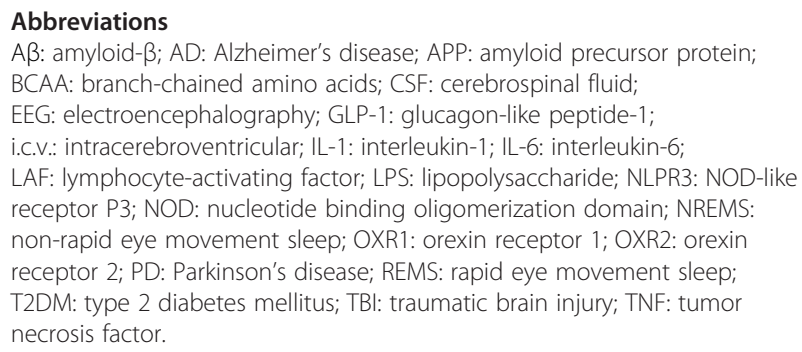

\section{Competing interests}

The authors declare that they have no competing interests.

\section{Authors' contributions}

IAC proposed the scope of the review. Both authors were involved in planning and editing the manuscript, blending their complementary expertise. Both authors read and approved the final manuscript.

\section{Acknowledgements}

No funding source was involved in the preparation of this article.

\section{Author details}

${ }^{1}$ Biomedical Sciences and Biochemistry, Research School of Biology, Australian National University, Acton, Canberra, Australian Capital Territory 0200, Australia. ${ }^{2}$ Neurodegeneration Research Group, Garvan Institute, 384 Victoria Street, Sydney, New South Wales 2010, Australia.

Received: 7 February 2014 Accepted: 11 March 2014

Published: 21 March 2014

\section{References}

1. Franchi L, Eigenbrod T, Nunez G: Cutting edge: TNF-a mediates sensitization to ATP and silica via the NLRP3 inflammasome in the absence of microbial stimulation. J Immunol 2009, 183:792-796.

2. Charles P, Elliott MJ, Davis D, Potter A, Kalden JR, Antoni C, Breedveld FC, Smolen JS, Eberl G, de Woody K, Feldmann M, Maini RN: Regulation of cytokines, cytokine inhibitors, and acute-phase proteins following antiTNF-a therapy in rheumatoid arthritis. J Immunol 1999, 163:1521-1528.
3. Le J, Vilcek J: Tumor necrosis factor and interleukin-1: cytokines with multiple overlapping biological activities. Lab Invest 1987, 56:234-248.

4. Zhang $Y$, Lin JX, Vilcek J: Synthesis of interleukin 6 (interferon- $\beta_{2} / B$ cell stimulatory factor 2) in human fibroblasts is triggered by an increase in intracellular cyclic AMP. J Biol Chem 1988, 263:6177-6182.

5. Hong S, Li R, Xu Q, Secombes CJ, Wang T: Two types of TNF-a exist in teleost fish: phylogeny, expression, and bioactivity analysis of Type-II TNF-a3 in rainbow trout Oncorhynchus mykiss. J Immunol 2013, 191(12):5959-5972.

6. Beck G, Vasta GR, Marchalonis JJ, Habicht GS: Characterization of interleukin-1 activity in tunicates. Comp Biochem Physiol B 1989, 92:93-98.

7. Kaslin J, Nystedt JM, Ostergard M, Peitsaro N, Panula P: The orexin/ hypocretin system in zebrafish is connected to the aminergic and cholinergic systems. J Neurosci 2004, 24:2678-2689.

8. LeRoith D, Lesniak MA, Roth J: Insulin in insects and annelids. Diabetes 1981, 30:70-76.

9. Clark IA, Alleva LE, Mills AC, Cowden WB: Pathogenesis of malaria and clinically similar conditions. Clin Microbiol Rev 2004, 17:509-539.

10. van Dullemen HM, van Deventer SJ, Hommes DW, Bijl HA, Jansen J, Tytgat GN, Woody J: Treatment of Crohn's disease with anti-tumor necrosis factor chimeric monoclonal antibody (cA2). Gastroenterology 1995, 109:129-135.

11. Chaudhari U, Romano P, Mulcahy LD, Dooley LT, Baker DG, Gottlieb AB: Efficacy and safety of infliximab monotherapy for plaque-type psoriasis: a randomised trial. Lancet 2001, 357:1842-1847.

12. Paramarta JE, Baeten D, De Rycke L: Synovial tissue response to treatment with TNF blockers in peripheral spondyloarthritis. Open Rheumatol J 2011, 5:127-132.

13. Elliott MJ, Maini RN, Feldmann M, Kalden JR, Antoni C, Smolen JS, Leeb B, Breedveld FC, Macfarlane JD, Bijl H, Woody JN: Randomised double-blind comparison of chimeric monoclonal antibody to tumour necrosis factor a (cA2) versus placebo in rheumatoid arthritis. Lancet 1994, 344:1105-1110.

14. Kiaei M, Petri S, Kipiani K, Gardian G, Choi DK, Chen J, Calingasan NY, Schafer P, Muller GW, Stewart C, Hensley K, Beal MF: Thalidomide and lenalidomide extend survival in a transgenic mouse model of amyotrophic lateral sclerosis. J Neurosci 2006, 26:2467-2473.

15. Travis SP, Czajkowski M, McGovern DP, Watson RG, Bell AL: Treatment of intestinal Behçet's syndrome with chimeric tumour necrosis factor a antibody. Gut 2001, 49:725-728.

16. Remberger $M$, Ringden $O$, Markling L: TNF a levels are increased during bone marrow transplantation conditioning in patients who develop acute GVHD. Bone Marrow Transplant 1995, 15:99-104.

17. Oka T, Hikoso S, Yamaguchi O, Taneike M, Takeda T, Tamai T, Oyabu J, Murakawa T, Nakayama H, Nishida K, Akira S, Yamamoto A, Komuro I, Otsu K: Mitochondrial DNA that escapes from autophagy causes inflammation and heart failure. Nature 2012, 485:251-255

18. Scharfe-Nugent A, Corr SC, Carpenter SB, Keogh L, Doyle B, Martin C, Fitzgerald KA, Daly S, O'Leary JJ, O'Neill LA: TLR9 provokes inflammation in response to fetal DNA: mechanism for fetal loss in preterm birth and preeclampsia. J Immunol 2012, 188:5706-5712.

19. Oliff A, Defeo-Jones D, Boyer M, Martinez D, Kiefer D, Vuocolo G, Wolfe A, Socher $\mathrm{SH}$ : Tumors secreting human TNF/cachectin induce cachexia in mice. Cell 1987, 50:555-563.

20. Smedley H, Katrak M, Sikora K, Wheeler T: Neurological effects of recombinant human interferon. BMJ 1983, 286:262-264.

21. McAdam KP, Li J, Knowles J, Foss NT, Dinarello CA, Rosenwasser LJ, Selinger MJ, Kaplan MM, Goodman R, Herbert PN, Bausserman LL, Nadler LM: The biology of SAA: identification of the inducer, in vitro synthesis, and heterogeneity demonstrated with monoclonal antibodies. Ann NY Acad Sci 1982, 389:126-136.

22. Krueger JM, Walter J, Dinarello CA, Wolff SM, Chedid L: Sleep-promoting effects of endogenous pyrogen (interleukin-1). Am J Physiol 1984, 246: R994-R999.

23. Carswell EA, Old LJ, Kassel RL, Green S, Fiore N, Williamson B: An endotoxin-induced serum factor that causes necrosis of tumors. Proc Natl Acad Sci USA 1975, 72:3666-3670.

24. Clark IA, Virelizier J-L, Carswell EA, Wood PR: Possible importance of macrophage-derived mediators in acute malaria. Infect Immun 1981, 32:1058-1066

25. Clark IA: Suggested importance of monokines in pathophysiology of endotoxin shock and malaria. Klin Wochenschr 1982, 60:756-758. 
26. Shoham S, Davenne D, Cady AB, Dinarello CA, Krueger JM: Recombinant tumor necrosis factor and interleukin-1 enhance slow-wave sleep. Am J Physiol 1987, 253:R142-R149.

27. Kapas $L$, Krueger JM: Tumor necrosis factor-beta induces sleep, fever, and anorexia. Am J Physiol 1992, 263:R703-R707.

28. Krueger JM, Takahashi S, Kapás L, Bredow S, Roky R, Fang J, Floyd R, Renegar KB, Guha-Thakurta N, Novitsky S, Obál F Jr: Cytokines in sleep regulation. Adv Neuroimmunol 1995, 5:171-188.

29. Floyd RA, Krueger JM: Diurnal variation of TNFa in the rat brain. Neuroreport 1997, 8:915-918.

30. Haack M, Pollmacher T, Mullington JM: Diurnal and sleep-wake dependent variations of soluble TNF- and IL-2 receptors in healthy volunteers. Brain Behav Immun 2004, 18:361-367.

31. Takahashi S, Tooley DD, Kapas L, Fang JD, Seyer JM, Krueger JM: Inhibition of tumor necrosis factor in the brain suppresses rabbit sleep. Eur J Physiol 1995, 431:155-160

32. Kapas L, Bohnet SG, Traynor TR, Majde JA, Szentirmai E, Magrath P, Taishi $P$, Krueger JM: Spontaneous and influenza virus-induced sleep are altered in TNF-a double-receptor deficient mice. J Appl Physiol 2008, 105:1187-1198.

33. Zielinski MR, Krueger JM: Sleep and innate immunity. Front Biosci (Schol Ed) 2011, 3:632-642

34. Slats $D$, Claassen JA, Verbeek MM, Overeem S: Reciprocal interactions between sleep, circadian rhythms and Alzheimer's disease: focus on the role of hypocretin and melatonin. Ageing Res Rev 2013, 12:188-200.

35. Williams JG, Bernstein S, Prager M: Effect of melatonin on activated macrophage TNF, IL-6, and reactive oxygen intermediates. Shock 1998, 9:406-411.

36. Sasaki M, Jordan P, Joh T, Itoh M, Jenkins M, Pavlick K, Minagar A, Alexander SJ: Melatonin reduces TNF- $a$ induced expression of MAdCAM-1 via inhibition of NF-KB. BMC Gastroenterol 2002, 2:9.

37. Espino J, Rodriguez AB, Pariente JA: The inhibition of TNF-a-induced leucocyte apoptosis by melatonin involves membrane receptor MT1/ MT2 interaction. J Pineal Res 2013, 54:442-452.

38. Fernandes PA, Cecon E, Markus RP, Ferreira ZS: Effect of TNF-a on the melatonin synthetic pathway in the rat pineal gland: basis for a 'feedback' of the immune response on circadian timing. J Pineal Res 2006, 41:344-350.

39. Li J, Hu Z, de Lecea L: The hypocretins/orexins: integrators of multiple physiological functions. Br J Pharmacol 2014, 171:332-350.

40. Alvarez CE, Sutcliffe JG: Hypocretin is an early member of the incretin gene family. Neurosci Lett 2002, 324:169-172.

41. Campbell JE, Drucker DJ: Pharmacology, physiology, and mechanisms of incretin hormone action. Cell Metab 2013, 17:819-837.

42. Chase $\mathrm{MH}$ : A unified survival theory of the functioning of the hypocretinergic system. J Appl Physiol 2013, 115:954-971.

43. Sutcliffe JG, de Lecea L: The hypocretins: excitatory neuromodulatory peptides for multiple homeostatic systems, including sleep and feeding. J Neurosci Res 2000, 62:161-168.

44. Fronczek R, Overeem S, Lee SY, Hegeman IM, van Pelt J, van Duinen SG, Lammers GJ, Swaab DF: Hypocretin (orexin) loss in Parkinson's disease. Brain 2007, 130:1577-1585.

45. Boutrel B, Cannella N, de Lecea L: The role of hypocretin in driving arousal and goal-oriented behaviors. Brain Res 2010, 1314:103-111.

46. Piper DC, Upton N, Smith Ml, Hunter AJ: The novel brain neuropeptide, orexin-A, modulates the sleep-wake cycle of rats. Eur J Neurosci 2000, $12: 726-730$

47. Iliff JJ, Lee $H, Y u M$, Feng $T$, Logan J, Nedergaard M, Benveniste H: Brain-wide pathway for waste clearance captured by contrast-enhanced MRI. J Clin Invest 2013, 123:1299-1309.

48. Xie L, Kang H, Xu Q, Chen MJ, Liao Y, Thiyagarajan M, O'Donnell J, Christensen DJ, Nicholson C, lliff JJ, Takano T, Deane R, Nedergaard M: Sleep drives metabolite clearance from the adult brain. Science 2013, 342:373-377.

49. Kang JE, Lim MM, Bateman RJ, Lee JJ, Smyth LP, Cirrito JR, Fujiki N, Nishino S, Holtzman DM: Amyloid- $\beta$ dynamics are regulated by orexin and the sleep-wake cycle. Science 2009, 326:1005-1007.

50. Ju YE, Lucey BP, Holtzman DM: Sleep and Alzheimer disease pathology - a bidirectional relationship. Nat Rev Neurol 2014, 10:115-119.

51. Torterolo P, Ramos OV, Sampogna S, Chase MH: Hypocretinergic neurons are activated in conjunction with goal-oriented survival-related motor behaviors. Physiol Behav 2011, 104:823-830
52. Xanthos DN, Sandkuhler J: Neurogenic neuroinflammation: inflammatory CNS reactions in response to neuronal activity. Nat Rev Neurosci 2014, 15:43-53.

53. Goldgaber D, Harris HW, Hla T, Maciag T, Donnelly RJ, Jacobsen JS, Vitek MP, Gajdusek DC: Interleukin 1 regulates synthesis of amyloid $\beta$-protein precursor mRNA in human endothelial cells. Proc Natl Acad Sci USA 1989, 86:7606-76010.

54. Donnelly RJ, Friedhoff AJ, Beer B, Blume AJ, Vitek MP: Interleukin-1 stimulates the beta-amyloid precursor protein promoter. Cell Mol Neurobiol 1990, 10:485-495.

55. Ge YW, Lahiri DK: Regulation of promoter activity of the APP gene by cytokines and growth factors: implications in Alzheimer's disease. Ann NY Acad Sci 2002, 973:463-467.

56. He P, Zhong Z, Lindholm K, Berning L, Lee W, Lemere C, Staufenbiel M, Li R, Shen $Y$ : Deletion of tumor necrosis factor death receptor inhibits amyloid $\beta$ generation and prevents learning and memory deficits in Alzheimer's mice. J Cell Biol 2007, 178:829-841.

57. Yamamoto M, Kiyota T, Horiba M, Buescher JL, Walsh SM, Gendelman HE, Ikezu T: Interferon- $\gamma$ and tumor necrosis factor- $\alpha$ regulate amyloid- $\beta$ plaque deposition and $\beta$-secretase expression in Swedish mutant APP transgenic mice. Am J Pathol 2007, 170:680-692.

58. Zhao J, O'Connor T, Vassar R: The contribution of activated astrocytes to $A \beta$ production: implications for Alzheimer's disease pathogenesis. J Neuroinflammation 2011, 8:150.

59. He P, Cheng X, Staufenbiel M, Li R, Shen Y: Long-term treatment of thalidomide ameliorates amyloid-like pathology through inhibition of $\beta$-secretase in a mouse model of Alzheimer's disease. PLoS One 2013, 8:e55091.

60. Medana IM, Day NP, Hien TT, Mai NT, Bethell D, Phu NH, Farrar J, Esiri MM, White NJ, Turner GD: Axonal injury in cerebral malaria. Am J Pathol 2002, 160:655-666.

61. Little CS, Hammond CJ, Maclntyre A, Balin BJ, Appelt DM: Chlamydia pneumoniae induces Alzheimer-like amyloid plaques in brains of BALB/C mice. Neurobiol Aging 2004, 25:419-429.

62. Miklossy J, Kis A, Radenovic A, Miller L, Forro L, Martins R, Reiss K, Darbinian N, Darekar P, Mihaly L, Khalili K: Beta-amyloid deposition and Alzheimer's type changes induced by Borrelia spirochetes. Neurobiol Aging 2006, 27:228-236.

63. McCoy JG, Strecker RE: The cognitive cost of sleep lost. Neurobio/ Learn Mem 2011, 96:564-582

64. Kalman J, Juhasz A, Bogats G, Babik B, Rimanoczy A, Janka Z, Penke B, Palotas A: Elevated levels of inflammatory biomarkers in the cerebrospinal fluid after coronary artery bypass surgery are predictors of cognitive decline. Neurochem Int 2006, 48:177-180.

65. Terrando N, Monaco C, Ma D, Foxwell BM, Feldmann M, Maze M: Tumor necrosis factor-a triggers a cytokine cascade yielding postoperative cognitive decline. Proc Natl Acad Sci USA 2010, 107:20518-20522.

66. Wu X, Lu Y, Dong Y, Zhang G, Zhang Y, Xu Z, Culley DJ, Crosby G, Marcantonio ER, Tanzi RE, Xie Z: The inhalation anesthetic isoflurane increases levels of proinflammatory TNF- $\alpha, \mathrm{IL}-6$, and IL-1 $\beta$. Neurobio Aging 2012, 33:1364-1378.

67. Zhang $Q$, Raoof M, Chen Y, Sumi Y, Sursal $T$, Junger W, Brohi K, Itagaki K, Hauser CJ: Circulating mitochondrial DAMPs cause inflammatory responses to injury. Nature 2010, 464:41-42.

68. Aurell J, Elmqvist D: Sleep in the surgical intensive care unit: continuous polygraphic recording of sleep in nine patients receiving postoperative care. Br Med J (Clin Res Ed) 1985, 290:1029-1032.

69. Friese RS, Diaz-Arrastia R, McBride D, Frankel H, Gentilello LM: Quantity and quality of sleep in the surgical intensive care unit: are our patients sleeping? J Trauma 2007, 63:1210-1214.

70. Alkadhi K, Zagaar M, Alhaider I, Salim S, Aleisa A: Neurobiological consequences of sleep deprivation. Curr Neuropharmacol 2013 11:231-249.

71. Frey DJ, Fleshner M, Wright KP Jr: The effects of 40 hours of total sleep deprivation on inflammatory markers in healthy young adults. Brain Behav Immun 2007, 21:1050-1057.

72. Hart BL: Biological basis of the behavior of sick animals. Neurosci Biobehav Rev 1988, 12:123-137.

73. Dantzer R, Kelley KW: Twenty years of research on cytokine-induced sickness behavior. Brain Behav Immun 2007, 21:153-160.

74. Dantzer R: Cytokine-induced sickness behavior: mechanisms and implications. Ann NY Acad Sci 2001, 933:222-234. 
75. Cavadini G, Petrzilka S, Kohler P, Jud C, Tobler I, Birchler T, Fontana A: TNF-a suppresses the expression of clock genes by interfering with E-boxmediated transcription. Proc Natl Acad Sci USA 2007, 104:12843-12848.

76. Hart PH, Whitty GA, Piccoli DS, Hamilton JA: Synergistic activation of human monocytes by granulocyte-macrophage colony-stimulating factor and IFN- $\gamma$. Increased TNF- $a$ but not IL-1 activity. J Immunol 1988, 141:1516-1521.

77. Clark IA, Budd AC, Alleva LM: Sickness behaviour pushed too far - the basis of the syndrome seen in severe protozoal, bacterial and viral diseases and post-trauma. Malar J 2008, 7:208.

78. Wu YH, Fischer DF, Kalsbeek A, Garidou-Boof ML, van der Vliet J, van Heijningen C, Liu RY, Zhou JN, Swaab DF: Pineal clock gene oscillation is disturbed in Alzheimer's disease, due to functional disconnection from the 'master clock'. FASEB J 2006, 20:1874-1876.

79. Bonanni E, Maestri M, Tognoni G, Fabbrini M, Nucciarone B, Manca ML, Gori S, ludice A, Murri L: Daytime sleepiness in mild and moderate Alzheimer's disease and its relationship with cognitive impairment. J Sleep Res 2005, 14:311-317

80. Lee JH, Bliwise DL, Ansari FP, Goldstein FC, Cellar JS, Lah JJ, Levey Al: Daytime sleepiness and functional impairment in Alzheimer disease. Am J Geriatr Psychiatry 2007, 15:620-626.

81. Rye DB: Excessive daytime sleepiness and unintended sleep in Parkinson's disease. Curr Neurol Neurosci Rep 2006, 6:169-176.

82. Poryazova R, Benninger D, Waldvogel D, Bassetti CL: Excessive daytime sleepiness in Parkinson's disease: characteristics and determinants. Eur Neurol 2010, 63:129-135.

83. Castriotta RJ, Murthy JN: Sleep disorders in patients with traumatic brain injury: a review. CNS Drugs 2011, 25:175-185.

84. Ponsford JL, Parcell DL, Sinclair KL, Roper M, Rajaratnam SM: Changes in sleep patterns following traumatic brain injury: a controlled study. Neurorehabil Neural Repair 2013, 27:613-621.

85. Bliwise DL, Rye DB, Dihenia B, Gurecki P: Greater daytime sleepiness in subcortical stroke relative to Parkinson's disease and Alzheimer's disease. J Geriatr Psychiatry Neurol 2002, 15:61-67.

86. Sterr A, Herron K, Dijk DJ, Ellis J: Time to wake-up: sleep problems and daytime sleepiness in long-term stroke survivors. Brain Inj 2008, 22:575-579.

87. Liu JC, Hung HL, Shyu YK, Tsai PS: The impact of sleep quality and daytime sleepiness on global quality of life in community-dwelling patients with heart failure. J Cardiovasc Nurs 2011, 26:99-105.

88. Riegel B, Ratcliffe SJ, Sayers SL, Potashnik S, Buck HG, Jurkovitz C, Fontana S, Weaver TE, Weintraub WS, Goldberg LR: Determinants of excessive daytime sleepiness and fatigue in adults with heart failure. Clin Nurs Res 2012, 21:271-293.

89. Nakanishi-Minami T, Kishida K, Funahashi T, Shimomura I: Sleep-wake cycle irregularities in type 2 diabetics. Diabetol Metab Syndr 2012, 4:18.

90. Ptitsyn AA, Zvonic S, Conrad SA, Scott LK, Mynatt RL, Gimble JM: Circadian clocks are resounding in peripheral tissues. PLoS Comput Biol 2006, 2:e16.

91. Tahara Y, Otsuka M, Fuse Y, Hirao A, Shibata S: Refeeding after fasting elicits insulin-dependent regulation of Per2 and Rev-erba with shifts in the liver clock. J Biol Rhythms 2011, 26:230-240.

92. Kuriyama K, Sasahara K, Kudo T, Shibata S: Daily injection of insulin attenuated impairment of liver circadian clock oscillation in the streptozotocin-treated diabetic mouse. FEBS Lett 2004, 572:206-210.

93. Ahren B: The future of incretin-based therapy: novel avenues - novel targets. Diabetes Obes Metab 2011, 1:158-166.

94. Dantzer R, Gheusi G, Johnson RW, Kelley KW: Central administration of insulin-like growth factor-1 inhibits lipopolysaccharide-induced sickness behavior in mice. Neuroreport 1999, 10:289-292.

95. Bluthe RM, Kelley KW, Dantzer R: Effects of insulin-like growth factor-I on cytokine-induced sickness behavior in mice. Brain Behav Immun 2006, 20:57-63.

96. Idris I, Abdulla H, Tilbrook S, Dean R, Ali N: Exenatide improves excessive daytime sleepiness and wakefulness in obese patients with type 2 diabetes without obstructive sleep apnoea. J Sleep Res 2013, 22:70-75.

97. Clark IA, Vissel B: Treatment implications of the altered cytokine-insulin axis in neurodegenerative disease. Biochem Pharmacol 2013, 86:862-871.

98. McClean PL, Holscher C: Liraglutide can reverse memory impairment, synaptic loss and reduce plaque load in aged APP/PS1 mice, a model of Alzheimer's disease. Neuropharmacology 2014, 76A:57-67.

99. Li Y, Perry T, Kindy MS, Harvey BK, Tweedie D, Holloway HW, Powers K, Shen H, Egan JM, Sambamurti K, Brossi A, Lahiri DK, Mattson MP, Hoffer BJ, Wang
Y, Greig NH: GLP-1 receptor stimulation preserves primary cortical and dopaminergic neurons in cellular and rodent models of stroke and Parkinsonism. Proc Natl Acad Sci USA 2009, 106:1285-1290.

100. Rachmany L, Tweedie D, Li Y, Rubovitch V, Holloway HW, Miller J, Hoffer BJ, Greig NH, Pick CG: Exendin-4 induced glucagon-like peptide-1 receptor activation reverses behavioral impairments of mild traumatic brain injury in mice. Age (Dordr) 2013, 35:1621-1636.

101. Tweedie D, Rachmany L, Rubovitch V, Lehrmann E, Zhang Y, Becker KG, Perez E, Miller J, Hoffer BJ, Greig NH, Pick CG: Exendin-4, a glucagon-like peptide-1 receptor agonist prevents $\mathrm{mTBl}$-induced changes in hippocampus gene expression and memory deficits in mice. Exp Neurol 2013, 239:170-182.

102. Darsalia V, Mansouri S, Ortsater H, Olverling A, Nozadze N, Kappe C, Iverfeldt K, Tracy LM, Grankvist N, Sjoholm A, Patrone C: Glucagon-like peptide-1 receptor activation reduces ischaemic brain damage following stroke in Type 2 diabetic rats. Clin Sci (Lond) 2012, 122:473-483.

103. Becskei C, Riediger T, Hernadfalvy N, Arsenijevic D, Lutz TA, Langhans W: Inhibitory effects of lipopolysaccharide on hypothalamic nuclei implicated in the control of food intake. Brain Behav Immun 2008, 22:56-64.

104. Gaykema RP, Goehler LE: Lipopolysaccharide challenge-induced suppression of Fos in hypothalamic orexin neurons: their potential role in sickness behavior. Brain Behav Immun 2009, 23:926-930.

105. Grossberg AJ, Zhu X, Leinninger GM, Levasseur PR, Braun TP, Myers MG Jr, Marks DL: Inflammation-induced lethargy is mediated by suppression of orexin neuron activity. J Neurosci 2011, 31:11376-11386.

106. Zhan S, Cai GQ, Zheng A, Wang Y, Jia J, Fang H, Yang Y, Hu M, Ding Q: Tumor necrosis factor-alpha regulates the Hypocretin system via mRNA degradation and ubiquitination. Biochim Biophys Acta 2011, 1812:565-571.

107. Baumann $C R$, Stocker $R$, Imhof HG, Trentz O, Hersberger M, Mignot E, Bassetti CL: Hypocretin-1 (orexin A) deficiency in acute traumatic brain injury. Neurology 2005, 65:147-149.

108. Baumann CR, Werth E, Stocker R, Ludwig S, Bassetti CL: Sleep-wake disturbances 6 months after traumatic brain injury: a prospective study. Brain 2007, 130:1873-1883

109. Patterson ZR, Holahan MR: Understanding the neuroinflammatory response following concussion to develop treatment strategies. Front Cell Neurosci 2012, 6:58.

110. Willie JT, Lim MM, Bennett RE, Azarion AA, Schwetye KE, Brody DL: Controlled cortical impact traumatic brain injury acutely disrupts wakefulness and extracellular orexin dynamics as determined by intracerebral microdialysis in mice. J Neurotrauma 2012, 29:1908-1921.

111. Chio CC, Chang CH, Wang CC, Cheong CU, Chao CM, Cheng BC, Yang CZ, Chang $C P$ : Etanercept attenuates traumatic brain injury in rats by reducing early microglial expression of tumor necrosis factor-a. BMC Neurosci 2013, 14:33.

112. Tobinick E, Kim NM, Reyzin G, Rodriguez-Romanacce H, DePuy V: Selective TNF inhibition for chronic stroke and traumatic brain injury: an observational study involving 629 consecutive patients treated with perispinal etanercept. CNS Drugs 2012, 26:1051-1070.

113. Deutschman CS, Raj NR, McGuire EO, Kelz MB: Orexinergic activity modulates altered vital signs and pituitary hormone secretion in experimental sepsis. Crit Care Med 2013, 41:e368-e375.

114. Liu L, Mills PJ, Rissling M, Fiorentino L, Natarajan L, Dimsdale JE, Sadler GR, Parker BA, Ancoli-srael S: Fatigue and sleep quality are associated with changes in inflammatory markers in breast cancer patients undergoing chemotherapy. Brain Behav Immun 2012, 26:706-713.

115. Kipnis J, Derecki NC, Yang C, Scrable H: Immunity and cognition: what do age-related dementia, HIV-dementia and 'chemo-brain' have in common? Trends Immunol 2008, 29:455-463.

116. Weymann KB, Wood $\mathrm{L}$, Zhu X, Marks DL: A role for orexin in cytotoxic chemotherapy-induced fatigue. Brain Behav Immun 2014, 37:84-94.

117. Jacob A, Brorson JR, Alexander JJ: Septic encephalopathy: inflammation in man and mouse. Neurochem Int 2011, 58:472-476.

118. Jurgens HA, Amancherla K, Johnson RW: Influenza infection induces neuroinflammation, alters hippocampal neuron morphology, and impairs cognition in adult mice. J Neurosci 2012, 32:3958-3968.

119. Brabers NA, Nottet HS: Role of the pro-inflammatory cytokines TNF- $a$ and IL-1 $\beta$ in HIV-associated dementia. Eur J Clin Invest 2006, 36:447-458.

120. Sonneville R, Ferrand H, Tubach F, Roy C, Bouadma L, Klein IF, Foucrier A, Regnier B, Mourvillier B, Wolff M: Neurological complications of HIV 
infection in critically ill patients: clinical features and outcomes. J Infect 2011, 62:301-308.

121. Clark IA, Cowden WB: The pathophysiology of falciparum malaria. Pharmacol Ther 2003, 99:221-260.

122. John CC, Panoskaltsis-Mortari A, Opoka RO, Park GS, Orchard PJ, Jurek AM, Idro R, Byarugaba J, Boivin MJ: Cerebrospinal fluid cytokine levels and cognitive impairment in cerebral malaria. Am J Trop Med Hyg 2008, 78:198-205.

123. Dauvilliers Y, Bisser S, Chapotot F, Vatunga G, Cespuglio R, Josenando T, Buguet A: Hypocretin and human African trypanosomiasis. Sleep 2008, 31:348-354.

124. Clark IA: Does endotoxin cause both the disease and parasite death in acute malaria and babesiosis? Lancet 1978, 2:75-77.

125. Clark IA, Awburn MM, Whitten RO, Harper CG, Liomba NG, Molyneux ME, Taylor TE: Tissue distribution of migration inhibitory factor and inducible nitric oxide synthase in falciparum malaria and sepsis in African children. Malar J 2003, 2:6.

126. Clark IA, Awburn MM, Harper CG, Liomba NG, Molyneux ME: Induction of HO-1 in tissue macrophages and monocytes in fatal falciparum malaria and sepsis. Malar J 2003, 2:41.

127. Dietrich J, Monje M, Wefel J, Meyers C: Clinical patterns and biological correlates of cognitive dysfunction associated with cancer therapy. Oncologist 2008, 13:1285-1295.

128. Wilson CM, Gaber MW, Sabek OM, Zawaski JA, Merchant TE: Radiationinduced astrogliosis and blood-brain barrier damage can be abrogated using anti-TNF treatment. Int J Radiat Oncol Biol Phys 2009, 74:934-941.

129. Parthsarathy $V$, Holscher $C$ : The type 2 diabetes drug liraglutide reduces chronic inflammation induced by irradiation in the mouse brain. Eur $\mathrm{J}$ Pharmacol 2012, 700:42-50.

130. Acuna-Goycolea C, van den Pol A: Glucagon-like peptide 1 excites hypocretin/orexin neurons by direct and indirect mechanisms: implications for viscera-mediated arousal. J Neurosci 2004, 24:8141-8152

131. Lowe XR, Bhattacharya S, Marchetti F, Wyrobek AJ: Early brain response to low-dose radiation exposure involves molecular networks and pathways associated with cognitive functions, advanced aging and Alzheimer's disease. Radiat Res 2009, 171:53-65

132. Ripley B, Overeem S, Fujiki N, Nevsimalova S, Uchino M, Yesavage J, Di Monte D, Dohi K, Melberg A, Lammers GJ, Nishida Y, Roelandse FW, Hungs M, Mignot E, Nishino S: CSF hypocretin/orexin levels in narcolepsy and other neurological conditions. Neurology 2001, 57:2253-2258.

133. Baumann CR, Hersberger M, Bassetti CL: Hypocretin-1 (orexin A) levels are normal in Huntington's disease. J Neurol 2006, 253:1232-1233.

134. Baumann CR, Scammell TE, Bassetti CL: Parkinson's disease, sleepiness and hypocretin/orexin. Brain 2008, 131:e91.

135. Compta Y, Santamaria J, Ratti L, Tolosa E, Iranzo A, Munoz E, Valldeoriola F Casamitjana R, Rios J, Marti MJ: Cerebrospinal hypocretin, daytime sleepiness and sleep architecture in Parkinson's disease dementia. Brain 2009, 132:3308-3317.

136. Friedman LF, Zeitzer JM, Lin L, Hoff D, Mignot E, Peskind ER, Yesavage JA: In Alzheimer disease, increased wake fragmentation found in those with lower hypocretin-1. Neurology 2007, 68:793-794.

137. Fronczek R, van Geest S, Frolich M, Overeem S, Roelandse FW, Lammers GJ, Swaab DF: Hypocretin (orexin) loss in Alzheimer's disease. Neurobiol Aging 2012, 33:1642-1650.

138. Thannickal TC, Lai YY, Siegel JM: Hypocretin (orexin) cell loss in Parkinson's disease. Brain 2007, 130:1586-1595.

139. Fronczek R, Overeem S, Lee SY, Hegeman IM, van Pelt J, van Duinen SG, Lammers GJ, Swaab DF: Hypocretin (orexin) loss and sleep disturbances in Parkinson's disease. Brain 2008, 131:e88.

140. Akbari $E$, Naghdi N, Motamedi F: The selective orexin 1 receptor antagonist SB-334867-A impairs acquisition and consolidation but not retrieval of spatial memory in Morris water maze. Peptides 2007, 28:650-656.

141. Soya S, Shoji H, Hasegawa E, Hondo M, Miyakawa T, Yanagisawa M, Mieda M, Sakurai T: Orexin receptor-1 in the locus coeruleus plays an important role in cue-dependent fear memory consolidation. J Neurosci 2013, 33:14549-14557.

142. Wayner MJ, Armstrong DL, Phelix CF, Oomura Y: Orexin-A (Hypocretin-1) and leptin enhance LTP in the dentate gyrus of rats in vivo. Peptides 2004, 25:991-996.
143. Akbari E, Motamedi F, Davoodi FG, Noorbakhshnia M, Ghanbarian E: Orexin1 receptor mediates long-term potentiation in the dentate gyrus area of freely moving rats. Behav Brain Res 2011, 216:375-380.

144. Yang L, Zou B, Xiong X, Pascual C, Xie J, Malik A, Sakurai T, Xie XS: Hypocretin/orexin neurons contribute to hippocampus-dependent social memory and synaptic plasticity in mice. J Neurosci 2013, 33:5275-5284.

145. Jaeger LB, Farr SA, Banks WA, Morley JE: Effects of orexin-A on memory processing. Peptides 2002, 23:1683-1688.

146. Ismail Z, Herrmann N, Rothenburg LS, Cotter A, Leibovitch FS, Rafi-Tari S, Black SE, Lanctot KL: A functional neuroimaging study of appetite loss in Alzheimer's disease. J Neurol Sci 2008, 271:97-103.

147. Sheard JM, Ash S, Mellick GD, Silburn PA, Kerr GK: Malnutrition in a sample of community-dwelling people with Parkinson's disease. PLoS One 2013, 8:e53290.

148. Haynes AC, Jackson B, Chapman H, Tadayyon M, Johns A, Porter RA, Arch JR: A selective orexin-1 receptor antagonist reduces food consumption in male and female rats. Regul Pept 2000, 96:45-51.

149. Akiyama M, Yuasa T, Hayasaka N, Horikawa K, Sakurai T, Shibata S: Reduced food anticipatory activity in genetically orexin (hypocretin) neuronablated mice. Eur J Neurosci 2004, 20:3054-3062

150. Kunii K, Yamanaka A, Nambu T, Matsuzaki I, Goto K, Sakurai T: Orexins/ hypocretins regulate drinking behaviour. Brain Res 1999, 842:256-261.

151. Albert SG, Nakra BR, Grossberg GT, Caminal ER: Vasopressin response to dehydration in Alzheimer's disease. J Am Geriatr Soc 1989, 37:843-847.

152. Cutler DJ, Morris R, Sheridhar V, Wattam TA, Holmes S, Patel S, Arch JR, Wilson S, Buckingham RE, Evans ML, Leslie RA, Williams G: Differential distribution of orexin-A and orexin-B immunoreactivity in the rat brain and spinal cord. Peptides 1999, 20:1455-1470.

153. Estabrooke IV, McCarthy MT, Ko E, Chou TC, Chemelli RM, Yanagisawa M, Saper CB, Scammell TE: Fos expression in orexin neurons varies with behavioral state. J Neurosci 2001, 21:1656-1662.

154. Kiyashchenko LI, Mileykovskiy BY, Maidment N, Lam HA, Wu MF, John J, Peever J, Siegel JM: Release of hypocretin (orexin) during waking and sleep states. J Neurosci 2002, 22:5282-5286.

155. Takakusaki K, Takahashi K, Saitoh K, Harada H, Okumura T, Kayama Y, Koyama Y: Orexinergic projections to the cat midbrain mediate alternation of emotional behavioural states from locomotion to cataplexy. J Physiol 2005, 568:1003-1020.

156. Zhang J, Li B, Yu L, He YC, Li HZ, Zhu JN, Wang JJ: A role for orexin in central vestibular motor control. Neuron 2011, 69:793-804.

157. Tsuneki H, Murata S, Anzawa Y, Soeda Y, Tokai E, Wada T, Kimura I, Yanagisawa M, Sakurai T, Sasaoka T: Age-related insulin resistance in hypothalamus and peripheral tissues of orexin knockout mice. Diabetologia 2008, 51:657-667.

158. Tsuneki H, Tokai E, Sugawara C, Wada T, Sakurai T, Sasaoka T: Hypothalamic orexin prevents hepatic insulin resistance induced by social defeat stress in mice. Neuropeptides 2013, 47:213-219.

159. Vgontzas AN, Zoumakis E, Lin HM, Bixler EO, Trakada G, Chrousos GP: Marked decrease in sleepiness in patients with sleep apnea by etanercept, a tumor necrosis factor- $a$ antagonist. J Clin Endocrinol Metab 2004, 89:4409-4413.

160. Zamarron C, Maceiras F, Mera A, Gomez-Reino JJ: Effect of the first infliximab infusion on sleep and alertness in patients with active rheumatoid arthritis. Ann Rheum Dis 2004, 63:88-90.

161. Irwin MR, Olmstead R, Valladares EM, Breen EC, Ehlers CL: Tumor necrosis factor antagonism normalizes rapid eye movement sleep in alcohol dependence. Biol Psychiatry 2009, 66:191-195.

162. Thaci D, Galimberti R, Amaya-Guerra M, Rosenbach T, Robertson D, Pedersen $R$, Yang $S$, Kuligowski M, Boggs R: Improvement in aspects of sleep with etanercept and optional adjunctive topical therapy in patients with moderate-to-severe psoriasis: results from the PRISTINE trial. J Eur Acad Dermatol Venereol 2013. doi:10.1111/jdv.12207.

163. Takahashi S, Kapas L, Fang JD, Krueger JM: An anti-tumor necrosis factor antibody suppresses sleep in rats and rabbits. Brain Res 1995 690:241-244.

164. Odessey R, Goldberg AL: Oxidation of leucine by rat skeletal muscle. Am J Physiol 1972, 223:1376-1383.

165. Muto Y, Sato S, Watanabe A, Moriwaki H, Suzuki K, Kato A, Kato M Nakamura T, Higuchi K, Nishiguchi S, Kumada H: Effects of oral branchedchain amino acid granules on event-free survival in patients with liver cirrhosis. Clin Gastroenterol Hepatol 2005, 3:705-713. 
166. Mattick JS, Kamisoglu K, lerapetritou MG, Androulakis IP, Berthiaume F: Branched-chain amino acid supplementation: impact on signaling and relevance to critical illness. Wiley Interdiscip Rev Syst Biol Med 2013, 5:449-460.

167. Lim MM, Elkind J, Xiong G, Galante R, Zhu J, Zhang L, Lian J, Rodin J, Kuzma $\mathrm{NN}$, Pack Al, Cohen AS: Dietary therapy mitigates persistent wake deficits caused by mild traumatic brain injury. Sci Transl Med 2013, 5:215ra173.

168. Cole JT, Mitala CM, Kundu S, Verma A, Elkind JA, Nissim I, Cohen AS: Dietary branched chain amino acids ameliorate injury-induced cognitive impairment. Proc Natl Acad Sci USA 2010, 107:366-371.

169. Betschart C, Hintermann S, Behnke D, Cotesta S, Fendt M, Gee CE, Jacobson LH, Laue G, Ofner S, Chaudhari V, Badiger S, Pandit C, Wagner J, Hoyer D: Identification of a novel series of orexin receptor antagonists with a distinct effect on sleep architecture for the treatment of insomnia. J Med Chem 2013, 56:7590-7607.

170. Jia X, Yan J, Xia J, Xiong J, Wang T, Chen Y, Qi A, Yang N, Fan S, Ye J, Hu Z: Arousal effects of orexin $A$ on acute alcohol intoxication-induced coma in rats. Neuropharmacology 2012, 62:775-783.

171. Deadwyler SA, Porrino L, Siegel JM, Hampson RE: Systemic and nasal delivery of orexin-A (Hypocretin-1) reduces the effects of sleep deprivation on cognitive performance in nonhuman primates. J Neurosci 2007, 27:14239-14247.

172. Weinhold SL, Seeck-Hirschner M, Nowak A, Hallschmid M, Goder R, Baier PC: The effect of intranasal orexin-A (hypocretin-1) on sleep, wakefulness and attention in narcolepsy with cataplexy. Behav Brain Res 2014, 262:8-13.

173. von der Goltz C, Koopmann A, Dinter C, Richter A, Grosshans M, Fink T, Wiedemann K, Kiefer F: Involvement of orexin in the regulation of stress, depression and reward in alcohol dependence. Horm Behav 2011, 60:644-650.

174. Hasegawa E, Yanagisawa M, Sakurai T, Mieda M: Orexin neurons suppress narcolepsy via 2 distinct efferent pathways. J Clin Invest 2014, 124:604-616.

doi:10.1186/1742-2094-11-51

Cite this article as: Clark and Vissel: Inflammation-sleep interface in brain disease: TNF, insulin, orexin. Journal of Neuroinflammation 2014 11:51.

\section{Submit your next manuscript to BioMed Central and take full advantage of:}

- Convenient online submission

- Thorough peer review

- No space constraints or color figure charges

- Immediate publication on acceptance

- Inclusion in PubMed, CAS, Scopus and Google Scholar

- Research which is freely available for redistribution 